\title{
Is it feasible and cost-effective to perform emergency ureteroscopic treatment for acute ureteric colic?
}

\begin{abstract}
Purpose: Ureteroscopy is one of the treatment options for the management of refractory ureteric colic. Emergency Ureteroscopy can provide significant symptomatic relief and may reduce the number of hospital attendances compared to Elective Ureteroscopy. Data regarding cost, however, is scarce.

Materials and methods: In this retrospective review, all patients who underwent ureteroscopic treatment for ureteric colic in the year 2015 were identified. Patients who underwent ureteroscopic during an emergency admission for acute ureteric colic were classified as having had Emergency Ureteroscopy, while those who underwent elective ureteroscopy for ureteric colic were classified as having had Elective Ureteroscopy. Exclusion criteria included urinary tract infection, sepsis, prior ureteroscopic procedures and/or ureteric stenting. The primary outcome evaluated was cost; secondary outcomes included number of preoperative attendances for colic, operative outcomes and complications, as well as hospital re-attendances.
\end{abstract}

Results: A total of 88 patients were identified, with 31 in the Emergency group, and 57 under the Elective group. EM was associated with significantly higher procedural and overall costs $(\mathrm{p}<0.001)$, but reduced hospital attendance for colic $(\mathrm{p}<0.001)$. There were no significant differences between both groups in terms of stone clearance rate and postoperative reattendances.

Conclusion: Emergency ureteroscopy management of ureteric colic is a reasonable treatment modality that reduces hospital attendance and has similar treatment outcomes as elective ureteroscopic treatment; albeit associated with higher financial costs.
Volume 4 Issue 4 - 2017

Siying Yeow
Khoo Teck Puat Hospital, Singapore

Correspondence: Siying Yeow, Khoo Teck Puat Hospital, 90 Yishun Central, Singapore, Tel +6590922082, Email siying.yeow@mohh.com.sg

Received: November 29, 2016 | Published: April 10, 2017

\section{Introduction}

Conventional modalities of management of acute ureteric colic included placement of a ureteric stent or nephrostomy tube. ${ }^{1-}$ ${ }^{3}$ Emergency ureteroscopic stone clearance is one of the emerging treatment modalities for acute ureteric colic, due to advancements in the field of endourology allowing safe and effective treatment with minimal morbidity. To date, there have been no published studies regarding the costs and outcomes of emergency ureteroscopy compared to elective ureteroscopy. Emergency ureteroscopy for definitive stone clearance may reduce costs, hospital reattendances for symptoms and prove to have comparable outcomes as elective ureteroscopy.

\section{Materials and methods}

This is an Ethics Board Committee-approved retrospective review of all patients who underwent ureteroscopy for definitive management of ureteric colic was performed from $1^{\text {st }}$ January 2015 to $31^{\text {st }}$ December at our institution. A total of 91 patients were identified. One patient from the Emergency ureteroscopy (EM) group and 2 patients from the Elective ureteroscopy (EM) group were excluded due to missing data. The exclusion criteria were the presence of an active urinary tract infection, sepsis, absence of colic symptoms at presentation, previous ureteric instrumention and/or procedures, and previous ureteric stenting. All patients were diagnosed with ureteric calculi either on X-ray, intravenous urography (IVU), or Computed Tomography (CT) imaging. The location of the calculi were defined as follows: upper ureter - from renal pelvis to superior sacroiliac joint; midureter - between superior and inferior sacroiliac joint; distal ureter - between inferior sacroiliac joint to vesicoureteric junction. All 88 patients underwent semirigidureteroscopy, with the possibility of using Holmium laser lithotripsy, forceps retrieval of stones and ureteric stenting if necessary.

Ureteroscopy was performed under general anaesthesia, with a 6.4F dual-channel semirigid ureteroscope (Olympus) under fluoroscopy. Laser lithotripsy was available if needed, with a $280 \mathrm{~nm}$ Holmium laser fiber (Lumenis). Ureteric stenting, when performed, was done under fluoroscopic guidance with a multilength $6 \mathrm{~F}$ ureteric stent (Boston Scientific). Ureteric stenting was performed at the discretion of the clinician, in cases with significant stone impaction, ureteric oedema, tight ureters with failure of access/requiring staged procedure(s), and in the presence of intraoperative ureteric injury. Stone-free status was confirmed at the end of the surgery with both endoscopic and fluoroscopic assessment. Statistical analysis was performed using SPSS (Statistical Package for the Social Sciences, Version 21.0). Chi-square test, linear regression and ANOVA test were used to compare parameters between the different groups. 


\section{Results}

The baseline parameters of both groups are seen in Table 1. There was no significant difference in the distribution of the stone locations in both groups. Patients who underwent EM had smaller calculi compared to EU (median $=5 \mathrm{~mm}$ vs $8 \mathrm{~mm}$ ). The majority in both groups had only a single calculus with a similar proportion of stone location being in the distal ureter or vesicoureteric junction (VUJ). Patients who underwent EU had a statistically higher number of preoperative attendance compared to those who underwent EM. In terms of surgical outcomes, EM was associated with a more challenging intraoperative environment with $32.4 \%$ of the patients having difficult ureteric access due to a tight ureter or a difficult ureteric angle. Proximal stone migration was encountered in $6.5 \%$ and $3.2 \%$ required the use of the flexible ureteroscope due to stone retropulsion intraoperatively.

Table I Patient and stone factors

\begin{tabular}{|c|c|c|c|}
\hline Variable & $\begin{array}{l}\text { Emergency } \\
\text { URS (EM) }\end{array}$ & $\begin{array}{l}\text { Elective } \\
\text { URS (EU) }\end{array}$ & p Value \\
\hline $\begin{array}{l}\text { Stone size }(\mathrm{mm}) \\
\leq 5 \\
6-10 \\
>10 \\
\text { Range } \\
\text { Median }\end{array}$ & $\begin{array}{l}18(58.0) \\
\text { II }(35.5) \\
2(6.5) \\
2-12 \\
5\end{array}$ & $\begin{array}{l}9(15.8) \\
36(63.2) \\
12(21.1) \\
2-20 \\
8\end{array}$ & $<0.001$ \\
\hline Multiple stones & $3(9.7)$ & $3(5.3)$ & NS \\
\hline $\begin{array}{l}\text { Stone location } \\
\text { Proximal ureter } \\
\text { Mid-ureter } \\
\text { Distal ureter } \\
\text { Vesicoureteric Junction } \\
\text { (VUJ) } \\
\text { Multiple locations }\end{array}$ & $\begin{array}{l}7(23.3) \\
2(6.7) \\
10(33.3) \\
7(23.3) \\
2(6.7)\end{array}$ & $\begin{array}{l}9(15.8) \\
11(19.3) \\
30(52.6) \\
5(8.8) \\
1(1.8)\end{array}$ & NS \\
\hline $\begin{array}{l}\text { Need for ureteric stenting } \\
\text { Yes } \\
\text { No }\end{array}$ & $\begin{array}{l}18(58.1) \\
13(41.9)\end{array}$ & $\begin{array}{l}21(36.8) \\
36(63.2)\end{array}$ & 0.08 \\
\hline $\begin{array}{l}\text { Number of hospital } \\
\text { attendances before } \\
\text { surgery } \\
\text { I } \\
2 \\
3-5 \\
6-10 \\
\text { Range } \\
\text { Median } \\
\text { Average }\end{array}$ & $\begin{array}{l}15(48.4) \\
8) 25.8) \\
8(25.8) \\
0(0.0) \\
1-5 \\
2 \\
1.9\end{array}$ & $\begin{array}{l}6(10.5) \\
10(19.6) \\
37(72.5) \\
4(7.8) \\
1-9 \\
3 \\
3.5\end{array}$ & $<0.001$ \\
\hline
\end{tabular}

Significantly, intraoperative complications, the need for staged procedures, stone-free rates, operative duration, and postoperative hospital reattendance rates were not significantly different between the 2 groups. Intraoperative complications included 1 case of ureteric perforation in the EM group and 3 cases of submucosal ureteric injury in the EL group. Staged procedures were required in 6 patients in the EM group for the following reasons:

Difficult stone access due to tight ureter in 3; Stone retropulsion into kidney in 2; and ureteric perforation in 1 after stone clearance-this patient underwent ureteric stenting and interval retrograde pyelogram and ureteric stent change.

Staged procedures were required in 5 patients in the EL group for the following reasons:

Difficult stone access due to tight ureter in 3; Incomplete stone fragmentation due to tight ureter in 1; And submucosal ureteric injury in 1 due to ureteric strictures distal to stone requiring ureterotomythis patient underwent ureteric stenting intraoperatively and had interval retrograde pyelogram and ureteroscopic evaluation. A higher proportion of those in the EM group required ureteric stenting $(58.1 \%$ vs $36.8 \%$ ) but this did not reach statistical significance. In terms of costs, EM was associated with a significantly higher cost of USD 943.3 for the primary procedure alone, and USD 1103.7 when the costs of staged procedures e.g. stent removal are included as well. On linear regression analysis, each additional day of hospitalization was an independent factor resulting in a significant additional cost of USD330.8 ( $\mathrm{p}<0.001)$. The placement of a ureteric stent was associated with an additional cost of USD 429.2 but this did not reach statistical significance $(\mathrm{p}=0.16)($ Table $2 \& 3)$.

Table 2 Surgical outcomes

\begin{tabular}{|c|c|c|c|}
\hline Factor & EM & EL & $p$ value \\
\hline $\begin{array}{l}\text { Intraoperative findings } \\
\text { Tight ureter/difficult ureteric } \\
\text { cannulation }\end{array}$ & $8(25.8)$ & $7(12.3)$ & NS \\
\hline Difficult ureteric angle & $2(6.5)$ & I ( I.8) & NS \\
\hline Proximal stone migration & $2(6.5)$ & $0(0.0)$ & NS \\
\hline Need for flexible URS & I ( 3.2) & $0(0.0)$ & NS \\
\hline Passed stone at surgery & $4(12.9)$ & $4(7.0)$ & NS \\
\hline $\begin{array}{l}\text { Failure of stone access } \\
\text { Due to tight ureter } \\
\text { Retropulsion back to kidney }\end{array}$ & $\begin{array}{l}3(9.7) \\
2 \\
1\end{array}$ & $\begin{array}{l}3(5.3) \\
3 \\
0\end{array}$ & NS \\
\hline $\begin{array}{l}\text { Intraoperative complications } \\
\text { Yes } \\
\text { No }\end{array}$ & $\begin{array}{l}\text { I (3.2) } \\
30(96.8)\end{array}$ & $\begin{array}{l}3(5.3) \\
54(94.7)\end{array}$ & 0.66 \\
\hline $\begin{array}{l}\text { Need for staged procedures } \\
\text { Yes } \\
\text { No }\end{array}$ & $\begin{array}{l}6(19.4) \\
25(80.6)\end{array}$ & $\begin{array}{l}5(18.8) \\
53(93.0)\end{array}$ & NS \\
\hline
\end{tabular}




\begin{tabular}{|c|c|c|c|}
\hline Factor & EM & EL & p value \\
\hline $\begin{array}{l}\text { Operative duration (minutes) } \\
\text { Median } \\
\text { Average } \\
\text { Range }\end{array}$ & $\begin{array}{l}40 \\
46 \\
5-117\end{array}$ & $\begin{array}{l}41 \\
42 \\
5-89\end{array}$ & NS \\
\hline $\begin{array}{l}\text { Need for DJ stent insertion } \\
\text { Yes } \\
\text { No }\end{array}$ & $\begin{array}{l}18(58.1) \\
13(48.9)\end{array}$ & $\begin{array}{l}21(36.8) \\
36(63.2)\end{array}$ & 0.08 \\
\hline $\begin{array}{l}\text { Stone-free post-op } \\
\text { Yes } \\
\text { No }\end{array}$ & $\begin{array}{l}27(87.1) \\
4(12.9)\end{array}$ & $\begin{array}{l}52(91.2) \\
5(8.8)\end{array}$ & NS \\
\hline Postoperative sepsis & $0(0.0)$ & $0(0.0)$ & NS \\
\hline $\begin{array}{l}\text { Duration of stay } \\
0 \\
1 \\
2 \\
3 \\
4 \\
\text { Median } \\
\text { Range }\end{array}$ & $\begin{array}{l}0 \\
2(6.5) \\
14(45.2) \\
8(25.8) \\
7(22.6) \\
2 \\
1-4\end{array}$ & $\begin{array}{l}52(91.2) \\
5(8.8) \\
0 \\
0 \\
0 \\
0 \\
0-1\end{array}$ & $<0.001$ \\
\hline Factor & EM & EL & $P$ value \\
\hline $\begin{array}{l}\text { Postoperative hospital } \\
\text { reattendance } \\
\text { Yes } \\
\text { No }\end{array}$ & $\begin{array}{l}2(6.5) \\
29(93.5)\end{array}$ & $\begin{array}{l}2(3.5) \\
55(96.5)\end{array}$ & NS \\
\hline
\end{tabular}

Table 3 Average cost and overall cost

\begin{tabular}{|l|l|l|l|}
\hline Average cost (USD) & EM & EL & P value \\
\hline Primary procedure & 301 I.I & 2067.8 & $<0.001$ \\
\hline $\begin{array}{l}\text { Cost of primary procedure } \\
\text { and stent removal }\end{array}$ & 3269.5 & 2242.7 & 0.001 \\
\hline $\begin{array}{l}\text { Overall cost, including } \\
\text { staged procedures }\end{array}$ & 3502.2 & 2398.5 & $<0.001$ \\
\hline
\end{tabular}

\section{Discussion}

EM has comparable stone-free rates and operative outcomes as elective ureteroscopy, albeit at a significantly higher cost. The cost of EM can be largely attributed to the duration of stay- $93.5 \%$ stayed for at least 2 days. This can be attributed to the following factors: failure after a trial of medical expulsion therapy (MET) would lead to the clinical decision for emergency ureteroscopy; the median waiting time for emergency surgery was $26 \mathrm{~h}$; and most patients would stay an additional day post-surgery for symptom monitoring before they are discharged. In contrast, EL is performed as Day Surgery procedures. ${ }^{4-6}$

\section{Conclusion}

EM is a reasonable option for acute management of ureteric colic, with comparable outcomes and stone-free rates as elective ureteroscopic surgery. Although overall costs are higher compared to elective surgery, patients enjoy quicker symptom relief, earlier return to work with potential reduction in health-related productivity loss.

\section{References}

1. Gettman MT, Segura JW. Management of ureteric stones: issues and controversies. BJU Int. 2005;95(suppl 2):85-93.

2. Joshi HB, Obadeyi OO, Rao PN. A comparative analysis of nephrostomy, JJ stent and urgent in-situ extracorporeal shock wave lithotripsy for obstructing ureteric stones. BJU Int. 1999;84(3):264-269.

3. Preminger GM, Tiselius HG, Assimos DG, et al. Guideline for the management of ureteral calculi. J Urol. 2007;178:2418-2434.

4. Sarica K, Tanriverdi O, Aydin M, et al. Emergency Ureteroscopic Removal of Ureteral Calculi After First Colic Attack: Is There Any Advantage? Urology. 2011;78(3):516-522.

5. Lotan Y, Gettman MT, Roehrborn CG, et al. Management of Ureteral Calculi: A Cost Comparison and Decision-Making Analysis. J Urol. 2002;167(4):1621-1629.

6. Youn JH, Kim SS, Yu JH, et al. Efficacy and Safety of Emergency Ureteroscopic Management of Ureteric Calculi. Korea $J$ Urol. 2012;53(9):532-563. 